\title{
Argentine University Libraries in 1956
}

$\mathrm{T}$ HERE ARE NOW seven universities in Argentina. These institutions of higher education, whose dates of founding range from 1622 to 1956 (Table I), are supported by the central government and, together with the National Library and a limited number of special libraries (chiefly in Buenos Aires), they possess the nation's chief research collectons. Although a recent article ${ }^{1}$ made brief mention of them, this report proposes to describe in greater detail the present status of their organization, resources, and services. It is based upon observations made during visits to all seven institutions in the fall of 1956 .

A glance at a map reveals how Argentina has distributed its universities to meet the needs of the country's population. Two of them, Buenos Aires and La Plata, serve the great concentraton of inhabitants in and around the capital. The new National University of the South offers higher educational facilities to Bahía Blanca and the other extreme of the province of Buenos Aires, as well as to the more sparsely populated provinces to the south, while Córdoba is located in the rapidly growing central region. Although the three remaining institutions-Cuyo, Tucumán, and Litoral -are centered at Mendoza, Tucumán, and Santa Fe respectively, they have some facilities in other cities in an attempt to meet better the educational needs of their regions. Thus, western Argentina, the Cuyo from which the uni-

1 Germán, García, "The Struggle for Libraries in Argentina," Library Journal, LXXXI (1956), 2642-46.

Dr. Jackson is librarian of the Undergraduate Library and assistant professor of library science, University of Illinois.
TABLE I

Argentine University Libraries

\begin{tabular}{lcc}
\hline \hline University & $\begin{array}{c}\text { Date } \\
\text { Founded }\end{array}$ & $\begin{array}{c}\text { Volumes } \\
\text { in Library* }\end{array}$ \\
\hline de Buenos Aires & 1821 & $1,300,000$ \\
de Córdoba & 1622 & $189,813^{\mathrm{a}}$ \\
de Cuyo & 1939 & 255,994 \\
de La Plata & 1890 & $340,000^{\mathrm{b}}$ \\
del Litoral & 1889 & 323,564 \\
del Sur & 1956 & 20,000 \\
de Tucumán & 1914 & 250,000 \\
\hline
\end{tabular}

* Note: Most figures are approximate.

a Main Library and faculty libraries only.

b Main Library and one faculty library only.

Sources: M. M. Chambers, ed., Universities of the World Outside $U$. S. A. (1st ed.; Washington, D. C., American Council on Education, 1950)-founding dates (except for South) and volumes at Tucumán; unpublished library figures.

versity takes its name, is served by one faculty each in San Juan and San Luis, as well as by those in Mendoza. Similarly, in the northwest, several departments of the University of Tucumán are located in Salta and Jujuy. The National University of the Litoral, serving northeastern Argentina, has divided its schools among three cities: Rosario, Santa Fe, and Corrientes.

\section{Administration}

In terms of libraries, Latin American universities fall into two groups: those having a centralized library serving the whole university and those served by "a series of separate faculty libraries, often subdivided into departmental and smaller unit libraries." ${ }^{2}$ The latter type has developed in Argentina, where not only does each faculty or school have its own autonomous library, but where most institutes and other departments also sup-

${ }^{2}$ Howard F. Cline, "American Books in Latin America," Library Trends, V (1956-57), 173. 
TABLE II

Distribution of Book Stock of University of Buenos Aires

\begin{tabular}{lrr}
\hline \hline \multicolumn{1}{c}{ Division } & Volumes & $\begin{array}{r}\text { Per Cent } \\
\text { of Total }\end{array}$ \\
\hline FACULTIES & & \\
$\quad$ Law and Social Sciences & 273,573 & 21.04 \\
Economic Sciences & 68,586 & 5.28 \\
Architecture and City Planning & 13,457 & 1.04 \\
Medical Sciences & 465,677 & 35.82 \\
Engineering & 34,160 & 2.63 \\
Natural and Exact Sciences & 39,768 & 3.06 \\
Philosophy and Letters & 79,467 & 6.11 \\
Agronomy and Veterinary Science & 68,952 & 5.30 \\
& & \\
Total & $1,043,640$ & 80.28 \\
INSTITUTES & $174,840^{\mathrm{b}}$ & 13.45 \\
National Colegio of Buenos Aires & 54,622 & 4.20 \\
Carlos Pellegrini Higher School of Commerce & 26,898 & 2.07 \\
\hline Grand Total & $1,300,000^{\mathrm{b}}$ & 100.00 \\
\hline
\end{tabular}

a Includes Faculty of Dentistry.

b Approximate figure.

SoUrce: Unpublished figures of Library Institute.

port small working collections for the use of their faculty and students. The libraries in the twenty-nine institutes of the Faculty of Philosophy and Letters at Buenos Aires (in addition to the general faculty library) exemplify such division, as do the thirty-nine units, ranging in size from less than two thousand to over fifty thousand volumes, which serve faculty and students at Tucumán. Each library forms a part primarily of the faculty or institute to which it belongs and only secondarily to the university's bibliothecal collection as a whole. However, it is apparent that the libraries within each system are now moving in the direction of centralization and coordination. Indeed, at Buenos Aires, this movement started in 1941, when the Superior Council (Consejo superior) established a Library Institute (Instituto bibliotecológico) as a coordinating agency for an already large and complex system. Those creating the Institute apparently envisaged it as a bibliographic center, with not only a central catalog of holdings of all the uni- versity's libraries but other tools and a photoduplication laboratory. Additional articles of the statute charged the Institute with responsibility for interlibrary loans, for coordination of resources, and for developing norms of cataloging and classification. $^{3}$ The Rockefeller Foundation provided $\$ 47,250$ in financial assistance for this project. ${ }^{4}$ Although the Institute has not, on the whole, lived up to the high hopes held for it as a coordinating agency, it has developed a central catalog. In fact, this and other central catalogs (discussed below) are specific indications of the trend toward centralization.

The concept of a general university library, not only as a coordinating agency but also as the unit providing centralized technical services and storage for a large part of the research collection, has to date developed only partially in Argentina and been implemented

3 Buenos Aires, Universidad Nacional, Instituto Bibliotecológico, Ordenanza de Creación del Instituto Bibliotecológico (Buenos Aires, 1953), pp. 3-7.

4 Rockefeller Foundation, Annual Report, 1942 (New York [1943]), p. 226, 287. 


\begin{tabular}{lrr}
\hline \hline \multicolumn{1}{c}{ Division } & Volumes & $\begin{array}{r}\text { Per Cent } \\
\text { of Total }\end{array}$ \\
\hline Main Library (Biblioteca mayor) & 100,000 & 52.68 \\
Faculty of Law and Social Sciences & 34,663 & 18.26 \\
Faculty of Medical Sciences & 16,750 & 8.83 \\
Faculty of Natural, Physical, and Exact Sciences & 15,800 & 8.32 \\
Faculty of Philosophy and Humanities & 16,100 & 8.48 \\
Faculty of Economic Sciences & 4,000 & 2.11 \\
Faculty of Architecture & 2,500 & 1.32 \\
& & 100.00 \\
\hline Total & 189,813 & 100.00 \\
\hline
\end{tabular}

* Main library and faculty libraries only. Some figures are estimates.

Source: Unpublished figures of Rector's Office and computations therefrom.

even less. La Plata, where a modern library building houses a large collection, has probably moved the most in this direction; but the central libraries at Tucumán and Cuyo are small in resources and staff and have yet to embark on centralized processing.

With present organization, then, it is obvious that responsibility for each university's libraries rests with a variety of people, including the deans and librarians of its various faculties; one does not find any position comparable to the American "director of libraries." But an indication of present thinking is the fact that the new University of the South plans to have a central administration, modeled on American universities and with its status embodied in the university statutes, for all libraries it may establish.

\section{Resources}

Argentine university libraries, like those in the United States, unquestionably constitute the most significant type of library from the standpoint of resources for advanced study and research. In fact, the University of Buenos Aires, if its collections are taken as a whole, is the country's largest and most important library. It is also, presumably, the largest university library in South Amer- ica, far surpassing that of the University of Chile, the largest reported in a 1954 tabulation. ${ }^{5}$ Incomplete statistics show that holdings of other universities ( $\mathrm{Ta}$ ble I), although not as impressive quantitatively, range from more than 189,000 to over 340,000 volumes, excluding the University of the South, founded in 1956 and just beginning to develop its library. But departmentalization tends to obscure the size of these collections. Tables II through IV show how such division has dispersed the holdings of three institutions. Although an examination of these statistics reveals few characteristics common to Buenos Aires, Córdoba, and Cuyo, it does serve to point out several facts which deserve brief comment. The eight faculty libraries of Buenos Aires contain 80 per cent of the total bookstock, but the two largest (Law and Medical Sciences) account for more than half. The Main Library alone at Córdoba has nearly the same percentage. Although Cuyo has schools in three cities, Table IV shows the concentration of library resources (about 90 per cent) in Mendoza.

Like most relatively young research libraries, those in Argentina have concentrated on developing their holdings

\footnotetext{
${ }^{5}$ Walter Crosby Eells, "Libraries in the Universities of the World," CRL, XV (1954), 435-39.
} 
of basic works, journal files, reference books, and the like-e.g., a few years ago the Medical Sciences Library at Buenos Aires was receiving 794 periodicals from thirty-three countries, including 166 from the United States. ${ }^{6}$ Nevertheless, the most serious handicap for current research in the republic is the lacunae in just such basic books and journals published abroad during the Perón epoch. Many periodical sets, for instance, lack at least some numbers for the years 1944-1955. It is now both difficult and expensive to secure these publications, whether monographs or serials. Since present funds must be spent largely on current acquisitions, it may be that a cooperative solution, perhaps with the assistance of outside funds, will be needed to solve the problem.

Because they have emphasized basic resources, Argentine university libraries have not purchased many rarities nor formed numerous special collections; gifts of books they have received for the most part have consisted of private libraries of general rather than specialized material. Nevertheless, there are a number of special collections.

Córdoba's Main Library houses in special quarters the material that belonged to Dalmacio Vélez Sársfield, author of the Argentine civil code. Presented to the University in 1883 by his son and daughter, this collection consists of the manuscripts of the code and his entire private library, including the works used in preparing the code and numerous other items in the field of law. Córdoba also has the books remaining of those the Jesuits possessed at the University before their expulsion in 1767. Although an inventory taken in 1771 showed 5,368 volumes, only about two thousand are left, because many were lost, sold during the struggle for independence, or transferred to the National Library in

- Buenos Aires, Universidad Nacional, Facultad de Ciencias Médicas, Boletín Bibliográfico (Buenos Aires, 1953).
TABLE IV

Distribution of Book STOCK OF UNIVERSITY of Cuyo

\begin{tabular}{|c|c|c|}
\hline Division & Volumes & $\begin{array}{l}\text { Per Cent } \\
\text { of Total }\end{array}$ \\
\hline \multicolumn{3}{|l|}{ MENDOZA } \\
\hline Central Library & 29,500 & 11.52 \\
\hline $\begin{array}{l}\text { Faculty of Philosophy } \\
\text { and Letters }{ }^{\mathrm{a}}\end{array}$ & 71,052 & 27.76 \\
\hline \multicolumn{3}{|l|}{ Faculty of Economic } \\
\hline Sciences & $12,909^{b}$ & 5.04 \\
\hline \multicolumn{3}{|l|}{ Faculty of Agrarian } \\
\hline Sciences & $26,139^{\mathrm{b}}$ & 10.21 \\
\hline \multicolumn{3}{|l|}{ Higher University } \\
\hline Council & 75,491 & 29.49 \\
\hline Other Divisions $^{e}$ & 14,927 & 5.83 \\
\hline Total & 230,018 & 89.85 \\
\hline \multicolumn{3}{|l|}{ SAN JUAN } \\
\hline \multicolumn{3}{|l|}{ Faculty of Engineering } \\
\hline \multicolumn{3}{|l|}{ Commercial School of } \\
\hline San Juan & 1,025 & .40 \\
\hline Total & 14,753 & 5.76 \\
\hline \multicolumn{3}{|l|}{ SAN LUIS } \\
\hline \multicolumn{3}{|l|}{ Faculty of Educational } \\
\hline Grand Total & 255,994 & 100.00 \\
\hline
\end{tabular}

a Divided among six institutes.

b Two libraries.

e Includes Combustion Institute, Conservatory of $\mathrm{Mu}$ sic and Scenic Art, School of Political Studies, University Club, Department of University Extension, and Central University Colegio.

Source: Unpublished figures of Central Library and computations therefrom.

Buenos Aires. Although works of philosophy and theology figure most prominently in the collection, there are titles from the fields of law, history, literature, and mathematics, as well as volumes dealing with the Jesuit order. ${ }^{7}$

La Plata possesses several special collections. Outstanding is the 18,000-volume Farini Library, purchased in 1936. It contains histories, descriptions, and travel accounts of the New World, many of them dating from the seventeenth and

'Juan B. Echenique, La Biblioteca Mayor, sus Origenes $y$ Desenvolvimiento (Córdoba, 1939), p. 3-5, $11-12,23-25$. 
eighteenth centuries. About 2,700 books of Argentine philosophy and literature compose the Alejandro Korn collection. The University also has a group of Cervantes items and more than 150 editions of the Rubáiyát.

In 1942 Dr. Modesto Álvarez Comas gave the Faculty of Juridical and Social Sciences of the University of the Litoral nearly eight hundred volumes and many pamphlets and periodicals. This collection centers on law and is especially rich in legal bibliography; it includes publications of the Argentine Supreme Court and nearly all treatises on Argentine law. ${ }^{8}$

The University of the South recently acquired the private library of the writer and critic Arthur Marasso. Used not only by Marasso but also by such Hispanists as Amado Alonso and Pedro Henriquez Ureña, it is primarily a working collection of basic texts and works of literary history and criticism, rather than an assemblage of rarities, although there are some early editions of important literary works. Comprising about three thousand volumes, it forms an excellent base on which to build the new University's resources in the Hispanic languages and literatures.

One of the most important collections of natural science in all South America has been formed by the Library of the Miguel Lillo Institute at the University of Tucumán. Created under the will of Argentine scientist Miguel Lillo (18621931), the Institute began operations in 1937 and engages in a program of teaching, research, and publication in a number of scientific fields; it is preparing, for example, the monumental Genera et Species Plantarum Argentinarum. Its library, embracing botany, zoology, entomology, geology, and mineralogy, now amounts to about fifty-four thousand items and is particularly rich in holdings

\footnotetext{
sDomingo Buonocore, La Biblioteca como Instru. mento de Cultura Universitaria (Santa Fe, 1942), p. $5-10$.
}

of scientific serials, of which more than six hundred titles are currently received. Among the notable books possessed are the Voyage of Humboldt and Bonpland (Paris, 1805-34) in twentyseven volumes, with hand-colored plates, and the first edition of the 40-volume set of Martius, Flora Brasiliensis. ${ }^{9}$

\section{Technical Services}

The technical services of Argentine university libraries reflect the lack of central administration and the dispersal of their collections. Each unit in a system, utilizing its own funds and personnel, generally has responsibility for its own acquisitions and cataloging. Here also developments are moving in the direction of centralization. The general library of the Faculty of Philosophy and Letters at Buenos Aires now handles acquisitions for the libraries of the Faculty's institutes, and it may refuse to duplicate holdings if it considers this unnecessary.

Among the methods of acquisition, purchase tends to be slow, time-consuming, and fraught with administrative difficulties (especially for serials), if judged by American standards. This results from fiscal and accounting policies usually beyond the control of the librarian. Funds available decreased steadily. under the Perón government, until they all but disappeared. Fortunately, present university budgets are providing relatively generous amounts, which, although by no means adequate for retrospective acquisition, appear in some cases ample for current publications. Problems of foreign currencies complicate procurement of books published abroad, particularly if a library seeks permission to use the official exchange rate of 18.50 pesos to the dollar instead of the free rate (which provides approximately half as many dollars).

\footnotetext{
"La Fundación "Instituto Miguel Lillo" de Tucumán (Argentina) ([Tucumán, n. d.]); José F. Molfino, Miguel Lillo (Tucumán, Editorial La Raza, 1948), p. 23 .
} 
Another method of acquisition, exchange, always important for Latin American libraries, became by far the most important source of additions during the Perón period. Some libraries report that as high as 80 or 90 per cent of their new volumes came by this method, while, at the same time, curtailed publication programs, by reducing the number of items they could offer, decreased the total amount of exchange. Here again the division of effort probably weakens the program; it is likely that centralized, or at least coordinated, exchange would achieve much better results than the total of existing individual programs. The Miguel Lillo Institute demonstrates what a successful exchange program can accomplish: by offering its journals in botany and zoology (Lilloa and Act Zoológicia Lilloana, respectively), it obtains nearly all its serials by exchange. Gifts, at present, play a relatively minor role in building library collections; this source might be more intensively cultivated in the future.

The number of units in Argentine universities and their physical separation make the lack of central catalogs one of the most serious obstacles in the way of adequate library organization. Not only do students and faculty spend considerable time searching for titles in various departmental libraries, but units unknowingly duplicate holdings of other divisions in the same system. As mentioned above, the Superior Council of the University of Buenos Aires in 1941 created a Library Institute to establish a central catalog for the resources of all university libraries. Although neither complete nor fully current, this tool, which incorporates more than six hundred thousand entries, is certainly a step in the right direction. At the time of its establishment, it was hoped to develop the catalog into a national union catalog by adding the holdings of other university libraries, the National Library, and other important collections, but this has not been realized. A central catalog at La Plata is about 50 per cent complete. In 1956 the administrations of the Universities of Cuyo and of Tucumán decided to create such catalogs at their institutions, but since budget, personnel, and equipment have not yet been made available, neither project has begun. Although Córdoba has a Bibliographic Office, containing cards from the Library of Congress and from other Argentine libraries, plans to develop a central catalog for the university remain tentative. The University of the South intends to list all books in a central catalog from the outset. This leaves only Litoral, which has not yet taken any steps in this direction. Although much remains to be done, it is clear that the prediction of further development of union catalogs in Argentina, made ten years ago, is being fulfilled. ${ }^{10}$

Catalogs in individual libraries vary greatly in type of entries, code followed (if any), and amount and arrangement of information provided. Practically no libraries have a dictionary catalog, but the author file is nearly universal, even in the smallest units. Except for serials and anonymous works, the title entry is almost non-existent, and the principle of corporate authorship has not found widespread adoption. Since there are no published periodical indexes, most catalogs include cards for magazine articles as well as other analytics. A classed catalog, based on the Universal Decimal Classification, most commonly provides the subject approach. The Faculty of Philosophy and Letters at Buenos Aires is one of the few libraries which follows modern cataloging principles (the Vatican code).

The classification most frequently encountered is the Universal Decimal Classification, in spite of the complications it introduces in shelving. However, some

${ }^{10}$ Carlos Victor Penna, "Union Catalogs in the Argentine Republic," CRL, VIII (1947), 436-37, 442. 
libraries-especially the smaller onesuse fixed location by accession number. Others have modified this to include broad subject grouping; such a system (somewhat indebted to the Library of Congress Classification) is found at the main library at La Plata.

\section{Services to Readers}

Many libraries occupy inadequate quarters which sometimes border on the makeshift. Areas used by the staff leave much to be desired; in some instances, no space remains to shelve current acquisitions, and capacity for readers is limited. Practically nowhere would the total provision in a system approach, percentagewise, that of most universities in the United States. For example, the library of the Faculty of Philosophy and Letters at Buenos Aires can seat only thirty-six people (less than 2 per cent of the two thousand students it serves). Unfortunately, such improvements as can be made at present (a small expansion of the Central Library at Tucumán, for instance) are temporary expedients rather than solutions to the spatial problem. The small roster of adequately housed libraries would include that of the Faculty of Medical Sciences at Buenos Aires and the Main Library at La Plata; both furnish a sufficient number of seats in their general reading rooms and have enough stack space for a number of years.

Turning now to services to readers, one notes that schedules maintained by most Argentine university libraries are surprisingly parallel to those in many American colleges and universities: from 8 A.M. to 10 P.M.; a few units open at $7: 30$, and some do not close until 11 . Some of the smaller collections do not provide service for two hours at midday, and no library presently offers any service on Sunday.

In circulation there appears to be a division between libraries with a liberal and those with a restrictive policy. Those in the former group have established loan periods of ten days or two weeks, while those in the latter limit borrowings to overnight or from Friday night to Monday morning; the usual explanation for the latter course is the great demand, especially for textbooks, which are so expensive (relative to students' funds) that they are not often purchased. Books on reserve usually meet such needs in American colleges and universities, but Argentine libraries with restrictive loan policies usually make no distinction between heavily used titles and those making up the general collection. In a few cases, complicated circulation procedures result in a great deal of staff work (usually transferring pertinent data from one ledger to another), but a critical re-evaluation of the raison d'être of charging systems is leading to gradual simplification of such cumbersome forms as do remain. Readers do not have direct access to the shelves in many of the larger libraries, but this is a less important question than in the United States, since fixed location of volumes by accession order removes the chief advantage of readers' examining the shelves. Libraries which employ a subject arrangement are more likely to have open shelves, as are most institutes and smaller units.

Of the four major library services, it is obvious that reference work has developed least in Argentine institutions of higher education. It would be interesting to know why this is so, but one can only speculate that lack of personnel, of space, and even of necessary reference tools have all contributed. In addition, it appears that librarians have concerned themselves less with the public service aspects of librarianship than with technical processes; there are administrators, catalogers, and circulation librarians in Argentine universities, but practically no reference librarians as such. Some libraries have not assembled their reference (Continued on page 422) 
ing conditions in the Soviet Union could not be). He has simply applied the old Marxist view of partisanship against objectivism in literature to the studies of bibliography.

In preparing his book, Zdobnov had to consult over 5,000 books and about 30,000 articles in sixty bibliographical and 700 general magazines of the eighteenth and nineteenth centuries. He divided his book into five parts: (1) the beginning period of Russian bibliog- raphy, from the eleventh to the seventeenth century; (2) the eighteenth century; (3) the first half of the nineteenth century; (4) the 1850 's and 1860 's; and (5) from the 1870 's to the beginning of the twentieth century. This third edition of the book was published in 10,000 copies, an indication of widespread interest in the history of bibliography in the U.S.S.R.-Milimir Drazic, Northwestern University Library.

\section{Argentine Libraries}

\section{(Continued from page 402)}

works in a convenient place. In short, whether or not users receive assistance and the quality of such service too often depend on chance, as opposed to organized reference work. However, as evidence of growing awareness of the importance of such work, one might cite the following: (1) use of enlarged book budgets to build up holdings of dictionaries, encyclopedias, bibliographies, handbooks, and the like, and (2) plans to establish reference or reference-circulation positions as soon as possible in several libraries now lacking such posts. The forthcoming publication of the first work in Spanish on reference books, by Josefa Emilia Sabor, librarian of the Faculty of Philosophy and Letters at Buenos Aires, should stimulate further interest in this area of librarianship.

The interpretation of public services has evolved unevenly in Argentina. Libraries utilize exhibits and displays, sponsor lectures on occasion and succeed in obtaining publicity in local newspapers and on radio stations. On the other hand, instruction in the use of the library, handbooks, and guides to collections remain relatively unexploited.

\section{Conclusion}

A review of the present organization, resources, and services of Argentine university libraries reveals a number of closely discernible trends. The first of these is the growing amount of centralization and coordination in each system; this may eventually lead to centralized library service, especially if some institutions carry out plans to build university cities. Second, if present funds continue to be available, these libraries will make substantial additions to their already important resources. Third, there is a tendency to re-evaluate library techniques and services and to reorganize them along more modern lines when necessary. All of these are positive developments. Assuming that such present problems as lack of central catalogs, lacunae in holdings of recent foreign publications, and inadequate space will be solved (this is not a small task, but present signs point to success), one can look forward expectantly to Argentine university libraries' serving better the growing needs of their faculties and students. 